Is reply to the letter in NATuke of May 29 (p. 3I9) under the heading ". Artificial Hiss," the following is a suggestion which may be an answer to the question, though not a practical solution to the problem.

A loud hissing noise accompanies the passing of an electric arc across the yap in such a lamp as is used for optical lanterns, \&c. Though this hissing noise does as a rule last for only a short time, yet it appears to me quite a simple matter to regulate the carbons so as to prolong the sound. The actual "hiss" sounds much more of a sibilant than an $f$. such as is produced by a current of air or steam being forced under pressure through a small opening.

Charterhouse, June 2.

H. I. KIEK.

\section{Red Water.}

In Nature of April 4, 1912, Messrs. Mackenzie and Finlay wrote relative to the cause of the occurrence of colouring matter in a sample of water from a crater lake in Uganda, and subsequently in the issues of April II and June 6 Messrs. $H$. Warth and $C$. Crossland respectively wrote describing the occurrence of similar characteristics in the great salt lake of Sambhar, in Rajputana, also pools at Suez, and near the Rawaya salt lake.

Dr. Gavin McCallum, in a paper read at a meeting of the Geelong Field Naturalists' Club, in March, rgIr, entitled "Forms of Life at the Salt-pans," directed attention to this coloration of the water and its blood-red appearance, and described it as being not due to the "colour of the liquid itself, but to the presence in enormous numbers of uniform small round cells. Dr. McCallum also mentions another form as being oval in shape with two cilia or lashes at the narrower end," the cilia and a small portion at the narrower end being colourless. At various times samples of the "red water" have been collected, and kept constantly under microscopical examination both by Dr. McCallum and myself, with the result that we can say the colouring is wholly due to a flagellate organism not unlike Polytoma uvella, Müll, as figured in the last edition of the "Encyclopædia Britannica," but as this is given as being a species of Chlamydomonadidæ in the article on Flagellata, and as a similar genus appears in the article on algæ by a different writer, some confusion evidently exists as to both these orders.

The oval form, as mentioned by Dr. McCallum, has two flagella, about one-third longer than the body, which appear to arise from a sort of collar or circular opening at the anterior end; there are two contractile vacuoles near the base of the flagella, and an eyespot; except the flagella and a small portion at the anterior end, the whole organism is so deeply pigmented with red matter that it is difficult to determine its constituent parts. There are other features, but these it is at present premature to mention. The globular form appears as the brine reaches saturation point, and is a sort of resting stage conditioned by the salinity of the medium in which it lives; this form gives rise to zoospores.

Associated with the flagellate organism is an interesting crustacean, the brine shrimp, very similar to Artemia salina, but in all the articles dealing with this crustacean the female is said to carry the eggs underneath the tail, whereas in this shrimp they are carried in sacs on either side, like the egg sacs of the Cyclops. The male, which is much larger than the female, has the usual claspers for holding the female. Dr. McCallum mentions in his article that at $7^{\circ}$ to $8^{\circ}$ Baume the shrimp sickens and dies; at this stage it becomes the host of the flagellate organism, which absorbs the decaying organic matter in the interior of the shrimp's body, leaving an absolutely hyaline cast skin.

I may mention that during this period of the organism's existence it is nearly always green, the red matter only making its appearance at a later stage. As the brine reaches crystallisation the ensuing salt is of a reddish hue, due, of course, to the pigmented organism, and it is a matter of conjecture as to whether or no each spherical monad does not form the nucleus of each crystal of salt. The salt, upon exposure to the sun, bleaches, but the zoospores contained within the spherical or globular membrane retain their vitality and issue forth in countless numbers of infinitely small green, actively moving flage!late organisms, upon redissolving the salt.

Geelong, Victoria, March 3r.

Fred WhitTeron.

\section{Phreatoicus in South Africa.}

At the beginning of this month I found some isopods in one of the swift-running streams on the top of Table Ylountain; they were quite common in and under the moss covering the stones in the bed of the stream, and were very sluggish. On examination they prove to belong to the family Phreatoicidæ. The occurrence in South Africa of a member of this peculiar family, which hitherto has been recorded only from New Zealand, Australia, and Tasmania, is of great interest as bearing on the question of the ancient land connection between the southern continents.

It is a new species, and will shortly be described in the Annals of the South African Museum.

KEPPEL H. BARNARD.

South African Museum, Cape Town,

Cape of Good Hope, May 20.

\section{GEOGRAPHY AND TRAVEL. ${ }^{1}$}

(1) THIS work has originated in the desire of its author to make some public statement of indebtedness. It is, as it were, a memorial laid upon an altar. Dr. Cornish, in his researches, has dealt with phenomena that are cosmic rather than humane; yet we now perceive them set against a background, old as that of the care-dwellers, where accomplishment is due to the fact that man does not live his life alone. Whether their vessel is rolling fifty-six degrees in the Bay of Biscay, or nearing Ceylon in incenseladen air, whether they are walking in the symbolic garden of the Shogun, or in the shattered streets of Kingston, the essential feature is that the travellers are together. The form adopted as a title merely adds emphasis to this impression.

Except for the stirring adventure of the Jamaican earthquake of 1907 , these travellers saw little that others have not seen and liberally described. But what they saw they realised as trained observers. "The greatest astronomical

1 (1) "The Travels of Ellen Cornish." Being the Memoir of a Pilgrim of Science. By Dr. Vaughan Cornish. Pp. xvi+293+plates+maps. (London: W. J. Ham-Smith, ror3.) Price r2s. $6 d$. net.

(2) " C C C (2) "The Continents and their People: Asia. A Supplementary Geography. By J. F. Chamberlain and A. H. Chamberlain. Pp. ix+rg8+ maps. (New York: The Macmillan Company; Iondon: Macmillan and Co., Ltd., 1913.) Price $3 s^{s}$

(3) "Modern Geography for High Schools." By R. D. Salisbury, H. H. Barrows, and W.S. Tower. Pp. ix $+418+$ vii plates. (New York: Henry Holt and Co., 1913.) Price 1.25 dollars.

(4) "Three Years in the Libyan Desert: Travels, Discoveries, and Excavations of the Menas Expedition." By J. C. Ewald Falls. Translated by Elizabeth Lee. Pp. xii $+356+$ plates. (London:T. Fisher Unwin, n.d.) Price $15 s$. net.

NO. 2276 , VOL. 9I] 
interest of a voyage to the equator is to get the completed view of the Milky Way." The truth of this is memorable, when one thinks of the successive streams of stars and the unfathomable spaces, changing night after night as the vessel swings down across the line. An area of cloud sailed under for twelve days in the North Pacific (p. go) is shown to have been as large as Australia. It "would form a considerable feature as seen from the moon. Presumably it would appear from there as a great bright patch." $\Delta t$ Niagara numerous observations were made on the forms of waves, and one of the fine photographic illustrations is here reproduced (Fig. I).
Dr. Cornish believes that the redistribution of load through erosion of the highland-axis north of Kingston caused a subsidence which propagated the shocks. He also has some remarks in the next chapter on earth-creep movements on the sides and noor of the Panama Canal.

It was finally Mrs. Cornish who wished, after a trying illness, to revisit Panama, "where things were being done which were worth doing." The book is a slight one, and is in no way a record of rescarch; but none will judge it lightly who can appreciate in scientific work the stimulus of complete companionship.

(2) The "supplementary greography" of Asia is

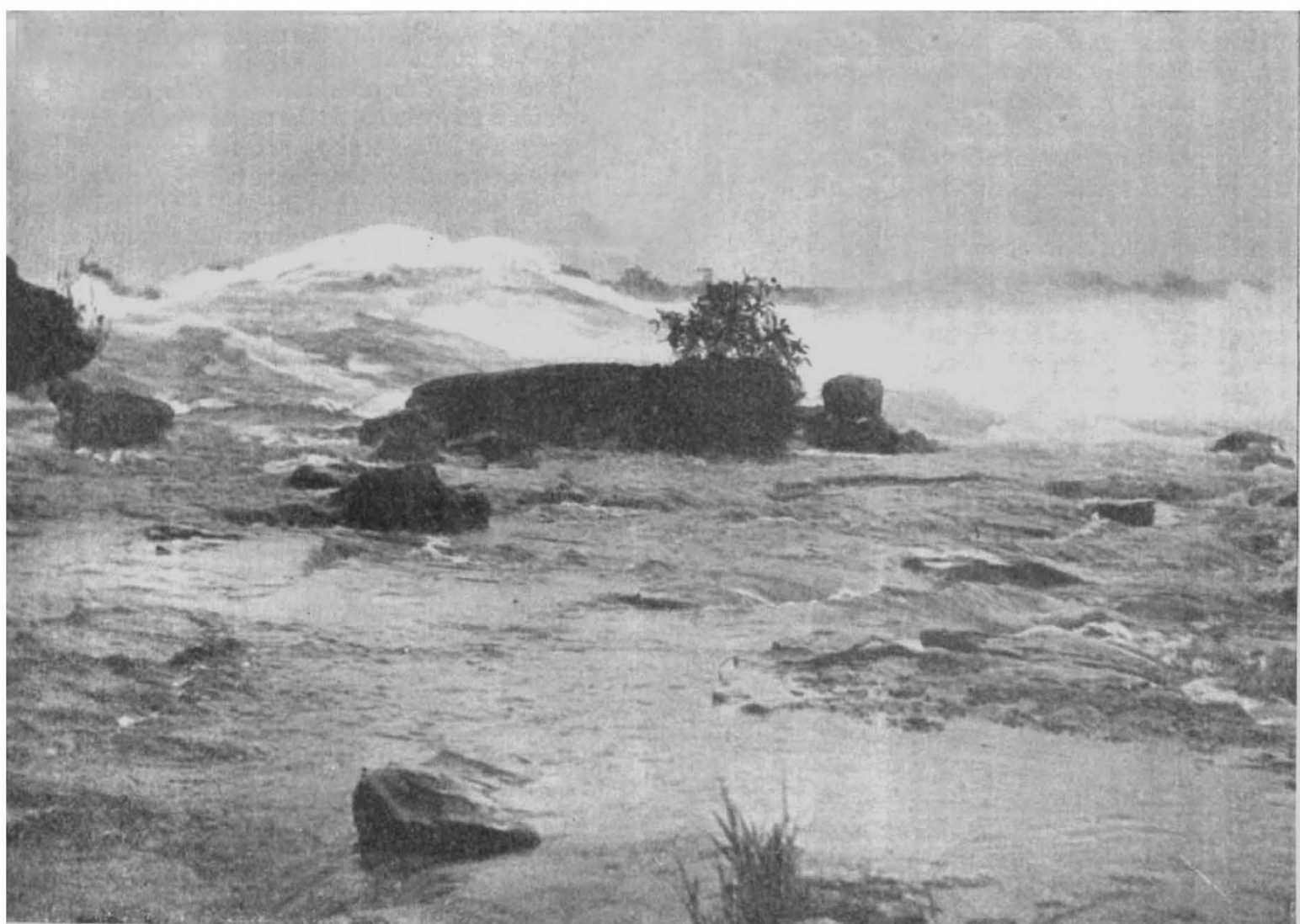

FIG. I.-Standing wave formed by a hidden rock, Upper Rapid, Niagara. From "The Travels of Ellen Cornish."

On p. I46 an interesting calculation is made as to how long, under modern conditions, it would take a traveller to see the world by daylight, and the "globe-trotter" is humbled when he learns that, by doing 300 miles a day, he would require I 36 years to appreciate the earth.

Ail reader's may learn something from the account of the destruction of Kingston, of the cameras carried out from the tottering house, and then put back with a fine perception when the human tragedy of the streets was realised (p. I84), of the later undulations felt upon a grass-lawn, and of the investigation of the causes of the shock when all still lay in ruin. presented by Messrs. Chamberlain in language suitable for an elementary class. Numerous photographs illustrate the human aspects of the subject, and these have evidently been selected so as to leave natural features as much as possible in the backyround. In fact, the book is in no sense a description of the continent, but it might well be read by pupils who have already become acquainted with the great contrasts of Asiatic structure, from the Arabian desert to the volcanic isles upon the east. This is, perhaps, implied in the subtitle of the book, which conveys very little geographical teaching of the kind now looked for in progressive schools. We can conceive its being

NO. 2276 , VOL. 9I] 
quite attractive as a gift-book, though twenty lines in cockney from Kipling's "Mandalay" will convey more of Asia than all the mediocre verse that is so freely quoted in its pages.

(3) The essential difference between the compact and detailed geography written by Messrs. Salisbury, Barrows, and Tower and the numerous recent American works on physical geography and physiography lies in the fact that this new book is mainly concerned with human relations to the earth's surface. But the groundwork of physical conditions is well laid. No attempt is made to describe the continents or the oceans, and this duty is probably left to the well-trained teacher and his wall-maps. Features met with on the earth are referred to their causes, and their effect on human enterprise is always kept in view. The United States are naturally selected as a groundwork for the illustration of general principles; but the book will serve admirably elsewhere in showing how teaching may be developed on these lines. "The need of salt," we are told (p. I83), "helped to hold most of the American colonists near the Atlantic coast for a long time." A quantity of salt that would now sell for some 30 cents cost 67 . ros. west of the Appalachian Mountains in 1778 . The general benefits resulting from the continental iceinvasion are described on p. 265. Soils are adequately dealt with, and the last i $5^{\circ}$ pages are concerned with such subjects as "the uses and problems of inland waters," irrigation, life in deserts and great forests, and the causes of the distribution of population. The book shows throughout how the problems of man's existence on the earth are fundamentally due to climate and topographic features. It provides, in fact, the kind of geography which every citizen should understand, whether he is developing a local industry or extending the borders of an empire.

(4) The three years spent by Mr. Falls with his cousin, Monsignor Kaufmann, in the Libyan desert were devoted to the discovery and excavation of the early Christian sanctuary of St. Menas. Incidentally, features of the desert and of the sodalakes are described; but the interest is naturally archæological. The photograph (p. r2o) of a Beduin with his gun, seated in the waste of cut stone that represents a lost city of the empire, is one of those impressive scenes that the camera most convincingly records. But behind the camera is needed the artist with the right imaginative perception. The author mentions incidentally that photographs can be taken from a camel-saddle. As a matter of fact, this high seat is ideal for a preliminary survey, and would probably be of service in the African bush, in place of viewing the landscape from occasional ant-hills.

Miss Lee's translation is usually clear and simple; but we have doubts about the "fields" of mica on p. 57 , while the account of snake-charming on pp. 303 and 304 is very puzzling. What are we to make of a "happy presentation" of snakes, or of "the Moses rod was only useful on the ground"?

$$
\text { NO. } 2276 \text {, VOL. 9I] }
$$

G. A. J. C.

\section{THE BIRMINGHAM MEETING OF THE} BRITISH ASSOCIATION.

\section{Arrangements for the Meeting.}

THE Birmingham meeting of the British Association next September promises to bu a notable one. Already more members have agreed to attend than has been the case at the corre. sponding period for the last few years, and the secretaries expect that the number both of local and of visiting members and associates togethe: will reach 3000 . But size, though an element in rendering the meeting notable, is not of the first importance, and it is the importance of the pronouncements made during the sessions which more than anything else stamps a meeting as of signal value. This may well be the case in Birminsham. The most important statement of the meeting is usually the presidential address, and since as president we are to have the principal of the Birmingham University, we may expect that Sir Oliver Lodge will deliver a notable pronouncement.

As a place of meeting Birmingham enjoys almost, perhaps quite, unrivalled facilities. Not merely is it centrally and accessibly situated, but its main buildings are placed unusually conveniently to one another, to the stations, and to the residential districts. A corridor or a street only intervene, as a rule, between two sections, so that the time often lost in passing from one section-room to another is here gained.

The centre of this system of sections is the reception room. This room serves almost every purpose except the one which its name implies. It is the bureau of information and headquarters of the association for the time being. It serves as the general meeting-ground, post-office, and place of supply of publications. On these accounts the town hall has been chosen, as being close to the railway and tram system.

Radiating from the town hall as a nucleus are the buildings in which the business of the association is transacted. The city council chamber will serve for the meetings of council, of the general committee, and of the committee of recommendations, the last being the financial body that allocates the grants of the association. The University building, Mason College, will contain eight out of the thirteen sections, and in addition there will be here a ladies' room, the Press bureau, the president's room, and the quarters of the permanent officers. Queen's College (no longer appertaining to the University) will lodge the economic section in its examination hall. The small lecture theatre of the Midland Institute will serve for the geographical section, whilst the closing meeting and probably the meetings of delegates will take place in the large theatre. In the Technical School, Suffolk Street, the sections devoted to engineering and chemistry will find their headquarters. Listly, anthropology has its meeting room in the Temperance Hall, Temple Street, and is therefore the only outlying section.

Among men of science from abroad who have accepted invitations to the meeting are:-- Prof. 